\title{
EVALUASI PROGRAM PENINGKATAN PERANAN WANITA MENUJU KELUARGA SEHAT DAN SEJAHTERA (P2WKSS)
}

\author{
Amalia Rahmadani Ilham dan Seno Andri \\ FISIP Universitas Riau, Kampus Bina Widya Km. 12,5 Simpang Baru Panam, Pekanbaru 28293
}

\begin{abstract}
Kampar Regency in Riau Province has implemented the P2WKSS program, the aim of which is to create a healthy and prosperous family with women as the driving force, but the phenomenon in the field is not the case. This study aims to evaluate the implementation of the Women's Role Improvement Program Towards Healthy and Prosperous Families (P2WKSS) in Kampar District and identify the inhibiting factors for the implementation of the P2WKSS program in Kampar District. This research use desciptive qualitative approach. Primary data obtained directly through interviews, observation and documentation. The results showed that the implementation of the P2WKSS program in Kampar District was still ineffective, where Kampar was late in implementing the program, the expected goals were not yet reached optimally, changes occurred only in the health aspect, but not in the education and economic aspects as expected. The implementation of the P2WKSS program has also not been efficient, where the program implementor has not been able to utilize time and maximize efforts to achieve program goals. Implementation of this program is also still not enough, where the implementation of the program has not been able to solve the problem, it actually raises new problems. This is due to several obstacles such as limited financial resources, human resources, facilities and infrastructure, implementor strategies, the creation of good communication, the recruitment of fostered people is still not selective, so it becomes the reason for not achieving the objectives of the P2WKSS program. It can be suggested that the P2WKSS program be continued with improvements in maximizing the budget for program implementation and synergy between program providers and recipients.
\end{abstract}

\begin{abstract}
Abstrak: Kabupaten Kampar Provinsi Riau telah melaksanakan program P2WKSS, tujuannya untuk mewujudkan keluarga sehat sejahtera dengan perempuan sebagai penggeraknya, namun fenomena dilapangan tidak demikian. Penelitian ini bertujuan untuk mengevaluasi pelaksanaan Program Peningkatan Peranan Wanita Menuju Keluarga Sehat Dan Sejahtera (P2WKSS) di Kabupaten Kampar serta mengidentifikasi faktor penghambat pelaksanaan program P2WKSS di Kabupaten Kampar. Penelitian ini menggunakan pendekatan deskriptif kualitatif. Data primer diperoleh langsung melalui wawancara, observasi dan dokumentasi. Hasil penelitian menunjukkan bahwa pelaksanaan program P2WKSS di Kabupaten Kampar masih belum efektif, dimana Kampar terlambat dalam melaksanakan program, tujuan yang diharapkan belum tercapai optimal, perubahan yang terjadi hanya pada aspek kesehatan, namun tidak pada aspek pendidikan dan ekonomi sebagaimana yang diharapkan. Pelaksanaan program P2WKSS juga belum efisien, dimana implementor program belum mampu memanfaatkan waktu dan memaksimalkan usaha untuk mencapai tujuan program. Pelaksanaan program ini juga masih belum cukup, dimana pelaksanaan program belum mampu memecahkan masalah, justru menimbulkan masalah baru. Hal ini dikarenakan beberapa hambatan seperti keterbatasan sumber daya financial, sumber daya manusia, sarana dan prasarana, strategi implementor, belum terciptanya komunikasi yang baik, perekrutan warga binaan masih belum selektif, sehingga menjadi sebab tidak tercapainya tujuan dari program P2WKSS. Dapat disarankan program P2WKSS dilanjutkan dengan perbaikan memaksimalkan anggaran penyelenggaraan program serta sinergitas antar penyelenggara dan penerima program.
\end{abstract}

Kata Kunci: evaluasi, program, peranan wanita, kebijakan publik

\section{PENDAHULUAN}

Sebagai salah satu Negara berkembang, kemiskinan merupakan permasalahan yang masih dihadapi oleh Indonesia. Pernyataan yang disampaikan oleh pengamat ekonomi dari Institute for Development of Economics and Finance (INDEF) mengenai hal ini adalah bahwa jumlah penduduk miskin masih menjadi persoalan yang mesti dicarikan solusi oleh pemerintah. Tidak terkecuali di Provinsi Riau. Tingkat kemiskinan di Provinsi Riau mengalami penurunan dan kenaikan setiap tahunnya. Data kemiskinan yang disajikan oleh Badan Pusat Statistik Riau menunjukkan bahwa Kabupaten Kampar merupakan salah satu Kabupaten yang ada diProvinsi Riau yang jumlah penduduk 
miskinnya terbilang banyak, dan mengalami penurunan dan peningkatan setiap tahunnya. Persentase jumlah penduduk miskin di Provinsi Riau per Kabupaten Tahun 2014 hingga 2018 juga mengalami penurunan dan peningkatan, pada tahun 2018 persentase penduduk miskin Kabupaten Kampar mengalami peningkatan yang cukup tinggi dibanding Kabupaten lainnya.

Di samping kemiskinan, perempuan pada saat sekarang ini juga menjadi isu prioritas $\mathrm{Na}$ sional. Berdasarkan data yang disajikan oleh Kementerian Perencanaan Pembangunan $\mathrm{Na}-$ sional (Bappenas, 2018) menunjukkan bahwa jumlah penduduk jenis kelamin perempuan di usia produktif lebih banyak dibanding jumlah penduduk laki-laki. Data dari Badan Pusat Statistik Riau juga menunjukkan bahwa jumlah penduduk perempuan di Provinsi Riau tidak berbeda jauh dibandingkan dengan jumlah penduduk laki-laki. Data tersebut menunjukkan bahwa Kabupaten Kampar merupakan Kabupaten yang memiliki jumlah penduduk perempuan terbanyak dibanding Kabupaten lainnya yang ada di Provinsi Riau setelah Kota Pekanbaru.

Masih rendahnya pembangunan diberbagai bidang seperti bidang pendidikan, kesehatan dan perekonomian mengharuskan perempuan untuk ikut serta mensejahterakan keluarga khususnya dan bangsa umumnya. Perlu adanya peranan perempuan dalam berbagai bidang pembangunan di daerah. Perempuan bisa menjadi potensi Negara untuk percepatan pembangunan Nasional apabila dibina dan diarahkan dengan baik.

Pemerintah telah melalukan berbagai upaya dalam kaitannya meningkatkan kesejahteraan masyarakat dan membantu percepatan pembangunan bangsa kedepannya, salah satunya yaitu dengan mengeluarkan Keputusan Menteri Negara Pemberdayaan Perempuan Nomor 41/Kep/ Meneg.pp/viii/2007 Tanggal 31 Agustus 2007 tentang Pedoman Umum Revitalisasi Program Peningkatan Peranan Wanita Menuju Keluarga Sehat Dan Sejahtera (P2WKSS).

Untuk mendukung keputusan yang sudah dikeluarkan oleh Menteri Negara Pemberdayaan Perempuan tersebut, maka Kementerian Dalam Negeri juga mengeluarkan Peraturan Menteri
Dalam Negeri Nomor 26 Tahun 2009 Tentang Pedoman Pelaksanaan Program Peningkatan Perananan Wanita Menuju Keluarga Sehat dan Sejahtera (P2WKSS) di Daerah. Kementerian Dalam Negeri mengeluarkan peraturan ini dengan tujuan bahwa dirasa perlu adanya peningkatan peranan wanita didaerah dilaksanakan dengan terarah, terkoordinasi, terpadu, dan berkesinambungan.

Dalam Keputusan Menteri Negara Pemberdayaan Perempuan Republik Indonesia No. 41 Tahun 2007 tentang Pedoman Umum Revitaliasi Program P2WKSS tersebut menegaskan bahwa Program P2WKSS merupakan program yang berupaya untuk mengembangkan sumber daya manusia dan sumber daya alam dan lingkungan untuk mewujudkan dan mengembangkan keluarga sehat, sejahtera dan bahagia dalam rangka pembangunan masyarakat desa/kelurahan, dengan perempuan sebagai penggeraknya. Selain untuk mengembangkan sumber daya manusia dan sumber daya alam di daerah, namun juga akan membantu meningkatkan ekonomi masyarakat miskin yang menjadi sasaran program.

Dalam rangka penanggulangan kemiskinan dan meningkatkan peran perempuan dalam meningkatkan kualitas hidup keluarga sekaligus membantu percepatan pembangunan Nasional, maka diharapkan program P2WKSS ini dapat terlaksana dengan sebaik mungkin dan memberikan dampak positif sesuai dengan tujuan dari dilaksanakannya program P2WKSS tersebut. Ginting (2017) mengemukakan pelaksanaan program P2WKSS di Kelurahan Sempakata Sumatera Utara tidak mengalami permasalahan dalam pelaksanaannya, namun dampak positif dari adanya program masih belum dirasakan oleh warga binaan seperti peningkatan perekonomian warga. Hal tersebut terjadi dikarenakan kurang tepat pada saat pendataan warga.

Pelaksanaan program P2WKSS di Kabupaten Kampar Provinsi Riau terdapat beberapa permasalahan. Berdasarkan data yang disajikan Badan Pusat Statistik Provinsi Riau, Kampar masih memiliki jumlah penduduk miskin yang semakin bertambah pada tahun 2018. Apabila dibandingkan dengan kabupaten lainnya di Provinsi Riau, Kabupaten Kampar dianggap ter- 
lambat dalam melaksanakan program P2WKSS ini. Fasilitas pada pelaksanaan Program P2WKSS tidak sesuai dengan jumlah warga binaan. Masyarakat susah untuk dikumpulkan. Masih banyak warga tidak mengetahui pelatihan maupun sosialisasi yang diberikan organisasi perangkat daerah sebagai implementor yang memberikan sosialisasi. Lagi pula pelaksanaan program P2WKSS lebih fokus kepada pengelolaan sumber daya alam dan lingkungan seperti pemberian bibit tanaman dan pola hidup sehat dan bersih. Warga binaan program P2WKSS khususnya wanita pada kategori pra sejahtera masih menjadi ibu rumah tangga tanpa mempraktekkan apa yang diperoleh dari pelatihan yang diberikan.

\section{METODE}

Jenis penelitian ini adalah penelitian evaluasi dengan pendekatan deskriptif kualitatif. Informan penelitian terdiri dari informan kunci, dipilih berdasarkan atas adanya tujuan tertentu dan beberapa pertimbangan, meliputi Kepala Dinas Pengendalian Penduduk, Keluarga Berencana, Pemberdayaan Perempuan dan Perlindungan Anak (DPPKBP3A) Kabupaten Kampar, Kepala Seksi Pelembagaan PUG dan Pemberdayaan Perempuan DPPKBP3A Kabupaten Kampar; Kepala Dinas Pemberdayaan Masyarakat dan Desa Kabupaten Kampar, Kepala Bidang Dinas Pemberdayaan Masyarakat dan Desa Kabupaten Kampar, Kepala Desa Sungai Putih Kecamatan Kampa, Kabupaten Kampar, Sekretaris Desa Sungai Putih Kecamatan Kampar, Kabupaten Kampar, Ketua TP-PKK Kabupaten Kampar, Ketua TP-PKK Kabupaten Kecamatan, Ketua TP-PKK Desa Sungai Putih Kecamatan Kampa, Kabupaten Kampar, Ketua P2WKSS Desa Sungai Putih Kecamatan Kampar, Kabupaten Kampar. Kemudian informan pendukung, dijadikan sebagai pembanding jawaban yang diperoleh dari infoman kunci. Mereka meliputi warga binaan program. Teknik pengumpulan data adalah observasi, wawancara dan dokumentasi. Analisis data bersifat deskriptif kualitatif, dimulai dengan mengolah data atau mengumpulkan data untuk dianalisis, membaca keseluruhan data, menganalisis lebih detail, mendeskripsikan semua informasi yang diperoleh, menyajikan deskripsi tersebut dengan laporan kualitatif, terakhir menginterpretasikan data atau memaknai data yang sudah diperoleh.

\section{HASIL DAN PEMBAHASAN Evaluasi Program P2WKSS Efektivitas}

Pelaksanaan program P2WKSS di Desa Sungai Putih Kecamatan Kampar Kabupaten Kampar dilihat dari aspek ekonomi belum mencapai kepada tujuannya, yaitu belum menunjukkan adanya peningkatan ekonomi pada warga binaan program P2WKSS. Hal ini dapat dilihat sebagaimana pada tabel berikut.

Tabel 1 Jumlah pendapatan beberapa warga binaan sebelum dan sesudah adanya program P2WKSS

\begin{tabular}{|c|c|c|c|c|}
\hline No & $\begin{array}{l}\text { Nama/ } \\
\text { Umur }\end{array}$ & $\begin{array}{l}\text { Pekerjaan/ } \\
\text { Pendidikan }\end{array}$ & $\begin{array}{c}\text { Pendapatan } \\
\text { sebelum } \\
\text { program (Rp) }\end{array}$ & $\begin{array}{c}\text { Pendapatan } \\
\text { sesudah program } \\
(\mathrm{Rp})\end{array}$ \\
\hline 1 & $\begin{array}{l}\text { Harsono } \\
\text { Sulastri } \\
\text { (53Thn) }\end{array}$ & $\begin{array}{l}\text { SLTP/ Petani/ } \\
\text { IRT }\end{array}$ & $\pm 1 \mathrm{jt} / \mathrm{bln}$ & $\pm 1 \mathrm{jt} / \mathrm{bln}$ \\
\hline 2 & $\begin{array}{l}\text { M.Lingga } \\
\text { Nurita } \\
\text { (44Thn) }\end{array}$ & $\begin{array}{l}\text { Tamat SD/ } \\
\text { Buruh tani/ } \\
\text { IRT }\end{array}$ & $\pm 800.000 / \mathrm{bln}$ & $\pm 800.000 / \mathrm{bln}$ \\
\hline 3 & $\begin{array}{l}\text { Nasep } \\
\text { (51 Thn) }\end{array}$ & $\begin{array}{l}\text { SLTP/ Petani/ } \\
\text { IRT }\end{array}$ & $\pm 800.000 / \mathrm{bln}$ & $\pm 800.000 / \mathrm{bln}$ \\
\hline 4 & $\begin{array}{l}\text { Sainem } \\
\text { (66Thn) }\end{array}$ & $\begin{array}{l}\text { Tamat SD/ } \\
\text { Pedagang } \\
\text { Tahu }\end{array}$ & $\pm 400.000 / \mathrm{bln}$ & $\pm 500.000 / \mathrm{bln}$ \\
\hline 5 & $\begin{array}{l}\text { Andi } \\
\text { (32Thn) }\end{array}$ & $\begin{array}{l}\text { STM/ Buruh } \\
\text { bangunan }\end{array}$ & $\pm 1,5 \mathrm{Jt} / \mathrm{bln}$ & $\pm 1,5 \mathrm{Jt} / \mathrm{bln}$ \\
\hline 6 & $\begin{array}{l}\text { Sofuaroh } \\
\text { Telaumban } \\
\text { (44Thn) }\end{array}$ & $\begin{array}{l}\text { Tamat SD/ } \\
\text { Wiraswasta }\end{array}$ & $\pm 2 \mathrm{Jt} / \mathrm{bln}$ & $\pm 2 \mathrm{Jt} / \mathrm{bln}$ \\
\hline 7 & $\begin{array}{l}\text { Kusnanto } \\
\text { Sumarti } \\
\text { (41Thn) }\end{array}$ & $\begin{array}{l}\text { SLTP/ } \\
\text { Wiraswasta/I } \\
\text { RT }\end{array}$ & $\pm 800.000 / \mathrm{bln}$ & $\pm 800.000 / \mathrm{bln}$ \\
\hline 8 & $\begin{array}{l}\text { Heri } \\
\text { Suparman } \\
\text { Jusrawati } \\
(42 T h n)\end{array}$ & $\begin{array}{l}\text { Tamat SD/ } \\
\text { Wiraswasta/I } \\
\text { RT }\end{array}$ & $\pm 1,8 \mathrm{Jt} / \mathrm{bln}$ & $\pm 1,8 \mathrm{Jt} / \mathrm{bln}$ \\
\hline 9 & $\begin{array}{l}\text { Ariadi } \\
\text { Suriatik } \\
\text { (52Thn) }\end{array}$ & $\begin{array}{l}\text { Tamat SD/ } \\
\text { Tukang/ } \\
\text { Pembantu }\end{array}$ & $\pm 2 \mathrm{Jt} / \mathrm{bln}$ & $\pm 2 \mathrm{Jt} / \mathrm{bln}$ \\
\hline 10 & $\begin{array}{l}\text { Sutiyono } \\
\text { Murniati } \\
\text { (37Thn) }\end{array}$ & $\begin{array}{l}\text { SLTP/ } \\
\text { Wiraswasta/ } \\
\text { IRT }\end{array}$ & $\pm 1,5 \mathrm{Jt} / \mathrm{bln}$ & $\pm 1,5 \mathrm{Jt} / \mathrm{bln}$ \\
\hline 11 & $\begin{array}{l}\text { Sunardi } \\
\text { Sariah } \\
\text { (47Thn) }\end{array}$ & SLTA/Petani & $\pm 800.000 / \mathrm{bln}$ & $\pm 800.000 / \mathrm{bln}$ \\
\hline 12 & $\begin{array}{l}\text { Endang } \\
\text { Suprianto } \\
\text { Saherni } \\
\text { (43Thn) }\end{array}$ & $\begin{array}{l}\text { SLTP } \\
\text { /Buruh } \\
\text { tani/Pedagang } \\
\text { gorengan }\end{array}$ & $\pm 1,2 \mathrm{Jt} / \mathrm{bln}$ & $\pm 1,2 \mathrm{Jt} / \mathrm{bln}$ \\
\hline 13 & $\begin{array}{l}\text { Tarmuji } \\
\text { Sapnah } \\
\text { (57Thn) }\end{array}$ & $\begin{array}{l}\text { Tamat SD/ } \\
\text { Buruh tani/ } \\
\text { IRT }\end{array}$ & $\pm 800.000 / \mathrm{bln}$ & $\pm 800.000 / \mathrm{bln}$ \\
\hline 14 & $\begin{array}{l}\text { Mursinah } \\
\text { (63 Thn) }\end{array}$ & & $\pm 500.000 / \mathrm{bln}$ & $\pm 500.000 / \mathrm{bln}$ \\
\hline 15 & $\begin{array}{l}\text { Dedi } \\
\text { Sudrajat } \\
\text { Azeni } \\
(28 T h n) \\
\end{array}$ & $\begin{array}{l}\text { SLTP/ } \\
\text { Wiraswasta/ } \\
\text { IRT }\end{array}$ & $\pm 1,5 \mathrm{Jt} / \mathrm{bln}$ & $\pm 1,5 \mathrm{Jt} / \mathrm{bln}$ \\
\hline
\end{tabular}

Sumber: Kantor Desa Sungai Putih Tahun 2020

Tabel 1 diatas menunjukkan bahwa dari beberapa warga binaan masih belum menunjukkan peningkatan terhadap pendapatan per 
bulannya. Hal ini dikarenakan belum diberikan pelayanan, baik berupa modal usaha maupun fasilitas penunjang distribusi.

Selain itu hasil di lapangan menunjukkan bahwa wanita sebagai warga binaan program P2WKSS di Desa Sungai Putih Kecamatan Kampar Kabupaten Kampar juga masih belum berdaya dan mengambil peran lebih dalam peningkatan kesejahteraan keluarganya, sebagaimana yang dapat dilihat pada tabel 2 berikut ini: Tabel 2 Mata pencaharian wanita warga binaan program P2WKSS Kabupaten Kampar

\begin{tabular}{llcc}
\hline No & Jenis Pekerjaan & $\begin{array}{c}\text { Laki-laki } \\
\text { (Orang) }\end{array}$ & $\begin{array}{c}\text { Perempuan } \\
\text { (Orang) }\end{array}$ \\
\hline 1 & Petani & 210 & - \\
2 & Buruh tani & 129 & - \\
3 & $\begin{array}{l}\text { Pegawai Negeri } \\
\text { Sipil }\end{array}$ & 10 & 5 \\
4 & $\begin{array}{l}\text { Pengrajin Industri } \\
\text { Rumah Tangga }\end{array}$ & - & 3 \\
5 & Pedagang Keliling & 1 & 1 \\
6 & Peternak & 20 & - \\
7 & Dokter & - & - \\
8 & Bidan & - & 1 \\
9 & Pensiunan & 1 & - \\
& TNI/Polri & & - \\
10 & Tukang & 3 & - \\
11 & Sopir & 20 & $\mathbf{1 0}$ \\
\multicolumn{2}{l}{ JUMLAH } & $\mathbf{4 1 4}$ & \\
\hline
\end{tabular}

Sumber: Kantor Desa Sungai Putih Tahun 2020

Pada aspek pendidikan juga masih belum mampu memberantas jumlah buta aksara di Desa Sungai Putih, sebagaimana yang diharapkan setelah adanya program P2WKSS tersebut, hingga sekarang pendidikan serta perubahan pola pikir warga binaan khususnya perempuan masih seperti sebelumnya dan hanya beberapa warga binaan yang mengalami perubahan pada kehidupannya setelah dilaksanakannya program P2WKSS tersebut. Hal ini dibuktikan dengan jumlah warga khususnya perempuan yang masih buta aksara, seharusnya dengan adanya program P2WKSS ini dapat memberantas dan meminimalisir jumlah buta aksara.

Bukan berarti tujuan dilaksanakannya program P2WKSS ini tidak tercapai secara keseluruhan, namun dilihat dari aspek kesehatan berdasarkan hasil dilpangan sudah sesuai sebagaimana yang diharapkan, warga binaan sudah menerapkan pola hidup bersih dan sehat (PHBS), kegiatan posyandu, pembinaan terhadap gizi lansia, ibu dan anak yang semakin aktif. namun memang dirasa belum optimal, seperti masih ada ditemukan jalur yang ada di desa tersebut yang masih mengalami kondisi seperti sebelumnya.

\section{Efisiensi}

Usaha yang dilakukan oleh pemerintah Kabupaten, Kecamatan dan desa selaku pihak penyelenggara dan juga memfasilitasi pelaksanaan program P2WKSS ini hanya memberikan bantuan bibit Hortikultura dan pelatihan peningkatan keterampilan namun belum adanya pelayanan dan pendampingan. Dana yang dianggarkan untuk pelaksanaan program P2WKSS ini dari PKK Kabupaten yang bersumber dari APBD hanya berkisar 35 juta, dan rentang waktu pelaksanaan program $\mathrm{P} 2 \mathrm{WKSS}$ ini adalah setiap tahun harus dilaporkan secara berkala kepada Pembina dan pengawas program seperti, provinsi dan pusat. Dengan dana dan waktu yang sudah ditetapkan, implementor program belum mampu untuk memanfaatkannya dengan baik demi mencapai tujuan dari pelaksanaan program P2WKSS itu sendiri.

\section{Kecukupan}

Pelaksanaan program P2WKSS di Desa Sungai Putih Kecamatan Kampa Kabupaten Kampar dilihat dari kriteria kecukupan, dapat dikatakan masih belum cukup memenuhi kebutuhan warga binaan, karena program ini dalam pelaksanaannya masih membingungkan beberapa warga binaan, permasalahan desa ini adalah masih rendahnya tingkat pendidikan, kesadaran akan pola hidup sehat yang masih minim, tingkat pendapatan yang masih rendah, dan setelah program ini dilaksanakan, masih belum mampu meminimalisir masalah-masalah tersebut, sebenarnya yang dibutuhkan warga itu bukan hanya pelatihan namun juga keberlanjutan modal dan pendampingan sistem pemasarannya.

\section{Pemerataan}

Pelaksanaan program P2WKSS di Desa Sungai Putih Kecamatan Kampa Kabupaten Kampar masih belum memenuhi kriteria pemerataan, karena manfaat serta pelayanan ada yang dibagikan secara merata seperti pemberian bibit 
tanaman hortikultura namun tidak diberikan sesuai porsinya kepada seluruh 60 orang warga binaan, selain itu manfaat dan pelayanan berupa pelatihan dan berbagai keterampilan tidak diberikan secara merata dan tidak sesuai porsinya, hasil dilapangan menunjukkan bahwa ada lebih dari satu keterampilan diikuti oleh orang yang sama. Sebagaimana yang tertera pada Tabel 3 berikutini:

Tabel 3 Namapeserta pelatihan dan keterampilan pada program P2WKSS

\begin{tabular}{|c|c|c|}
\hline No & Pelatihan & Nama peserta \\
\hline 1 & Merajut & Dewi minarni \\
\hline 2 & & Murniati \\
\hline & Tata boga & \\
\hline 3 & Quilting & $\begin{array}{l}\text { Dewi minarni } \\
\text { Elvia }\end{array}$ \\
\hline & & $\begin{array}{l}\text { Dwi novita sari } \\
\text { Revita apriliani }\end{array}$ \\
\hline 4 & Membatik & $\begin{array}{l}\text { Dwi novita sari } \\
\text { Revita apriliani } \\
\text { Resti sri wahyuni }\end{array}$ \\
\hline
\end{tabular}

Sumber: DPPKBP3A Kabupaten Kampar Tahun 2020

Pada tabel 3 diatas dapat diketahui bahwa pada jenis pelatihan yang berbeda-beda namun diikuti oleh orang yang sama.

\section{Responsivitas}

Antara pemerintah maupun warga binaan masih kurang responsive, karena pemerintah desa, pemerintah kecamatan maupun pemerintah kabupaten belum menginformasikan secara menyeluruh mengenai program P2WKSS, kemudian ketika warga binaan menanyakan kejelasan program, pemerintah desa merespon dengan kurang baik, seharusnya pemerintah desa lebih pro aktif terhadap pertanyaan-pertanyaan warga bahkan pemerintah desa sebagai pemerintah di desa berupaya membangkitkan semangat warga untuk berpartisipasi aktif dalam menyukseskan program ini.

\section{Ketepatan}

Program P2WKSS di Desa Sungai Putih Kecamatan Kampa Kabupaten Kampar ini masih belum tepat. Belum tepat yang dimaksud adalah dalam pelaksanaannya masih belum tepat waktu, pemerintah Kabupaten Kampar, di- anggap terlambat dalam melaksanakan program P2WKSS ini, seharusnya dibentuk dan dilaksanakan sesuai dengan ketentuan peraturan Menteri Dalam Negeri yaitu tahun 2009, namun dengan jarak waktu yang lama Kampar baru melaksanakan progam ini di tahun 2017, dan pada tahun 2017 tersebut semangat dan komitmen antar penyelenggara masih belum ada, sehingga pelaksanaan program ini tidak tepat waktu. Pada saat pelaksanaan ditahun 2017 hingga 2019, penyelenggara program juga masih belum tepat waktu dalam melaksanakan setiap kegiatan pada program P2WKSS.

Pelaksanaan program ini juga masih belum tepat sasaran, karena apabila mengacu kepada Peraturan Menteri Dalam Negeri No 26 Tahun 2009 menegaskan bahwa pemiihan desa binaan program P2WKSS adalah desa yang dianggap miskin dan rawan terhadap pendidikan, kesehatan dan ekonomi, dan berdasarkan hasil observasi dan wawancara di lapangan, ternyata pemilihan desa binaan didasarkan bukan hanya desa miskin, namun jarak tempuh juga dipertimbangkan oleh pihak penyelenggara progarm, padahal desa yang pantas dijadikan desa binaan itu adalah desa-desa yang di Kampar Kiri, Namun karena jarak tempuh jauh, Kabupaten menggeser desa binaan ke daerah yang bisa dijangkau, tentu ini sebenarnya tidak sesuai dengan regulasi yang ada.

\section{Faktor Penghambat Pelaksanaan Program P2WKSS \\ Keterbatasan Sumber Daya Financial}

Pemerintah Kabupaten Kampar dalam hal ini pihak penyelenggara, baik DPPKBP3A, pihak Kecamatan maupun desa tidak menganggarkan dana yang lebih untuk penyelenggaraan kegiatan pada program P2WKSS ini. Dengan keterbatasan dana dan waktu, implementor program belum mampu memanfaatkannya dengan baik.

\section{Keterbatasan Sumber Daya Manusia}

Bagaimana mungkin program ini akan terlaksana dengan baik apabila pihak penyelenggara itu sendiri belum mengetahui secara keseluruhan mengenai program yang akan 
dilaksanakan serta belum mampu untuk menyusun rencana kerja kelompok dengan baik. Seharusnya sebelum melaksanakan tiga kegiatan dalam pelaksanaan program P2WKSS ini, pihak penyelenggara harus menyusun rencana kerja kelompok terlebih dahulu guna lancarnya kegiatan yang akan dilaksanakan. Baiknya pelaksanaan program, salah satunya ditentukan oleh sumber daya manusianya. Apabila suatu program ini dilaksanakan dengan baik oleh sumber daya manusia yang kompeten, maka tujuan dari program itu sendiri akan dapat tercapai dengan optimal.

\section{Keterbatasan Sarana dan Prasarana}

Fasilitas penunjang pelatihan seperti mesin jahit, dan bahan serta alat lainnya tidak dapat mengcover seluruh warga binaan dikarenakan minimnya dana untuk melaksanakan program P2WKSS ini.

\section{Keterbatasan Strategi Implementor}

Implementor masih belum sepenuhnya bertanggung jawab atas program P2WKSS ini, apabila sebagian warga binaan tidak begitu antusias terhadap program tersebut, namun pihak pelaksana membiarkan begitu saja, sehingga kurangnya komitmen dan strategi implementor mengakibatkan program P2WKSS ini tidak terlaksana sebagaimana mestinya. Dari keragaman perilaku sasaran program ini sebaiknya beragam pula bentuk pendekatannya. Hal ini berkaitan dengan implementor program P2WKSS di Kabupaten Kampar belum mempunyai strategi dalam melaksanakan program ini dengan baik.

\section{Rekrutmen Belum Selektif}

Masih ada warga yang memang miskin dan rumahnya sederhana terbuat dari kayu, namun tidak termasuk kedalam warga binaan program, sementara disisi lain yang sejatinya tidak terlalu memenuhi kriteria namun menjadi warga binaan, hal ini dikarenakan pemilihan warga binaan diserahkan kepada desa karena menjadi hak perogratif desa, dalam praktiknya masih adanya warga yang seharusnya mendapatkan manfaat dari program P2WKSS ini, namun tidak diikut sertakan.

\section{Keterbatasan Komunikasi}

Informasi yang disampaikan oleh implementor program kepada warga sebagai penerima program kurang jelas, baik komunikasi antara impelementor dengan penerima program, bahkan antar sesama implementor program P2WKSS tersebut. Dengan kurangnya komunikasi mengenai program P2WKSS ini menyebabkan munculnya konflik, bukan hanya konflik antar pemerintah desa dengan warga, bahkan antarwarga itu sendiri. Sehingga kebanyakan dari warga binaan tidak mengetahui apa itu sebenarnya program P2WKSS.

\section{SIMPULAN}

Pelaksanaan Program P2WKSS di Kabupaten Kampar masih belum efektif, dimana rencana kerja kelompok belum disusun dengan baik, tujuan yang diharapkan belum tercapai dengan optimal dibuktikan dengan perubahan yang terjadi hanya pada aspek kesehatan saja seperti peningkatan kesadaran warga untuk membangun pola hidup bersih dan sehat (PHBS), namun pada aspek ekonomi, warga binaan belum mengalami peningkatan pendapatan dibanding sebelum adanya program, kemudian pada aspek pendidikan belum adanya peningkatan penurunan angka buta aksara di desa tersebut. Pelaksanaan program P2WKSS di Kabupaten Kampar juga masih belum efisien, dimana implementor program belum mampu memanfaatkan waktu yang ada dengan memak-simalkan usaha untuk mencapai tujuan dengan optimal. Usaha yang dilakukan oleh pelaksana program baik bentuk usaha berupa financial maupun bentuk usaha berupa tindakan masih belum mampu untuk mencapai hasil yang diinginkan. Selain itu, masih belum adanya keberlanjutan baik dari segi fasilitas pendukung produksi, modal maupun kerjasama dengan pihak ketiga untuk mendistribusikan hasil produksi warga, padahal yang dibutuhkan warga bukan hanya sebatas pelatihan namun diharapkan adanya keberlanjutan berupa modal awal dan bentuk kerjasama untuk pemasarannya dan pembentukan koperasi wanita dilakukan sebagai sarana untuk peningkatan perekonomian warga binaan sebagaimana yang diamanatkan dalam regulasi yang ada. 
Pelaksanaan program ini juga masih belum cukup, dimana pelaksanaan program P2WKSS tersebut belum mampu memecahkan masalah di Desa Sungai Putih, justru menimbulkan masalah baru dikalangan warga desa bahkan dengan pemerintah desaitu sendiri. Pelaksanaan program P2WKSS di Kabupaten Kampar juga masih belum merata, dimana manfaat serta pelayanan belum diberikan secara merata dan sesuai porsinya kepada seluruh warga binaan. Pelaksanaan program P2WKSS juga masih belum responsive, dimana warga masih ada yang tidak menghiraukan program P2WKSS ini. Selain itu, dalam pelak-sanaannya program P2WKSS juga dinilai masih belum tepat, dimana penerima program ini tidak tepat sasaran, masih ada desa yang seharusnya pantas dijadikan sebagai desa binaan namun tidak disertakan karena dengan alasan jarak tempuh yang akan dilalui implementor sangat jauh.

Pelaksanaan program P2WKSS di Kabupaten Kampar juga belum tepat waktu, seharusnya dibentuk dan dilaksanakan sesuai dengan ketentuan peraturan Menteri Dalam Negeri yaitu tahun 2009 dan paling lambat tahun 2010, namun dengan jarak waktu yang lama Kampar baru melaksanakan progam ini di tahun 2017. Pada saat pelaksanaan ditahun 2017 hingga 2019, implementor program juga masih belum tepat waktu dalam melaksanakan setiap kegiatan pada program P2WKSS tersebut, seperti hanya mengunjungi desa binaan dalam satu tahun tiga kali saja dengan waktu yang tidak ditentukan. Hal tersebut dikarenakan oleh beberapa faktor penghambat diantaranya keterbatasan sumber daya Fianancial, kebeterbatasan sumber daya manusia, keterbatasan sarana dan prasarana, keterbatasan strategi implementor, keterbatasan komunikasi, kesalahan dalam merekrut warga binaan, maka tujuan dari pelaksanaan program ini masih belum dapat tercapai dengan optimal.

\section{DAFTAR RUJUKAN}

Agustino, Leo. 2014. Dasar-Dasar Kebijakan Publik. Bandung: CV Alfabeta.

Anderson, James, A. 1998. Public Police Making: Basic Consep In Political Science. New York: Prayeger University Series.
Creswell, John. W. 2010. Research Desain Pendekatan Kualitatif, Kuantitatif, dan Mixed. Yogyakarta: Pustaka Pelajar.

Dunn, William, N. 2003. Pengantar Analisis Kebijakan Publik. Yogyakarta: Gadjah Mada University Press.

Darmayanti. 2010. Evaluasi Program Pemberdayaan Ekonomi Masyarakat Pesisir (PEMP) Studi Kasus Swamitra Mina Pantura Jaya, Cilincing, Jakarta Utara dan Swamitra Mina Mitra Usaha Muara Gembong Jawa Barat. Tesis Mahasiswa Universitas Indonesia.

Dwi Arieska Setyaningrum, dkk. 2019. Evaluasi Program Terpadu Peningkatan Peranan Wanita Menuju Keluarga Sehat dan Sejahtera (P2WKSS) di Desa Badang Kecamatan Ngoro Kabupaten Jombang (Studi Pada Sektor Ketahanan Pangan). Jurnal Mahasiswa Universitas Negeri Surabaya. Vol. 7. No. 3.

Heskiela Adi Wibowo. 2017. Dampak Program P2WKSS Terhadap Kesejahteraan Keluarga Miskin di Kelurahan Keparakan, Kecamatan Mergangsan, Kota Yogyakarta. Jurnal Mahasiswa Universitas Negeri Yogyakarta. Vol.6 No. 3.

Haryono. 2010. Studi Evaluasi Program Pemberdayaan Masyarakat: Kasus Program Pengembangan Kecamatan (PPK) di Kabupaten Bogor. Disertasi Mahasiswa Universitas Indonesia.

Intan Septiani. 2018. Pemberdayaan Perempuan Melalui Program Peningkatan Peran Wanita Menuju Keluarga Sehat Sejahtera (P2WKSS) (Studi Deskriptif di Desa Binangun Kecamatan Pataruman Kota Banjar). Tesis Mahasiswa Universitas Islam Negeri Sunan Gunung Djati Bandung.

Irene, Astuti Dwiningrum. 2011. Desentralisasi dan Partisipasi Masyarakat dalam Pendidikan. Yogyakarta: Pustaka Pelajar. Islamy, Irfan. 2004. Prinsip-prinsip Perumusan Kebijaksanaan Negara. Jakarta: Bumi Aksara

Rivai, Veithzal, 2009. Manajemen Sumber Daya Manusia untuk Perusahaan. Jakarta: Raja Grafindo Persada. 
Lugiarti, E. 2004. Partisipasi Masyarakat dalam Proses Pembangunan. Jakarta: Khanata

Mustopadidjaja. 2009. Manajemen Proses Kebijakan Publik Formulasi, Implementasi, dan Evaluasi Kinerja. Jakarta: LAN dan Duta Pertiwi.

Rosda, Malia. 2018. Peran Serta Perempuan Dalam Program Terpadu P2WKSS POKJA III di Desa Kertajaya Kecamatan Ciranjang Kabupaten Cianjur. Jurnal Agroscience Universitas Surya Kencana. Vol. 6.

Sartana. 2011. Evaluasi Pelaksanaan Program Sekolah MenengahAtas Bertaraf Internasional di Provinsi Lampung Rintisan Tahun 2016. Tesis Mahasiswa Universitas Indonesia. Subarsono. 2011. Analisis Kebijakan Publik:
Konsep Teori dan Aplikasi. Yogyakarta: Pustaka Pelajar.

Suharto, Edi. 2010. Analisis Kebijakan Publik. Bandung: Alfabeta.

Wahab, Solichin Abdul. 2014. Analisis Kebijaksanaan dari Formulasi ke Implementasi Kebijaksanaan Negara. Jakarta: Bumi Aksara.

Winarno, Budi. 2012. Kebijakan Publik Teori, Proses dan Studi Kasus. Yogyakarta: CAPS.

Yenchilia Damanik. 2016. Evaluasi Kebijakan Penanggulangan Kemiskinan Melalui Program Pelatihan Keterampilan di Kelurahan Mangunharjo, Kecamatan Tembalang, Kota Semarang. Jurnal Kebijakan Publik dan Manajemen. Vol. 5. No. 3. 